\title{
Mononuclear piano-stool iron 2- ethynylbenzo[b]thiophene complex: crystal structure and reversible oxidation studied by spectro-electrochemical and DFT methods
}

Article

Accepted Version

Ou, Y.-P., Zhang, J., Kuang, D., Zhang, F., Yu, J., Zhu, X., Liu, S. H. and Hartl, F. (2017) Mononuclear piano-stool iron 2ethynylbenzo[b]thiophene complex: crystal structure and reversible oxidation studied by spectro-electrochemical and DFT methods. Journal of Coordination Chemistry, 70 (4). pp. 722-733. ISSN 0095-8972 doi:

https://doi.org/10.1080/00958972.2016.1278434 Available at https://centaur.reading.ac.uk/68113/

It is advisable to refer to the publisher's version if you intend to cite from the work. See Guidance on citing.

To link to this article DOI: http://dx.doi.org/10.1080/00958972.2016.1278434

Publisher: Taylor \& Francis

All outputs in CentAUR are protected by Intellectual Property Rights law, including copyright law. Copyright and IPR is retained by the creators or other copyright holders. Terms and conditions for use of this material are defined in 
the End User Agreement.

www.reading.ac.uk/centaur

\section{CentAUR}

Central Archive at the University of Reading

Reading's research outputs online 


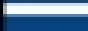

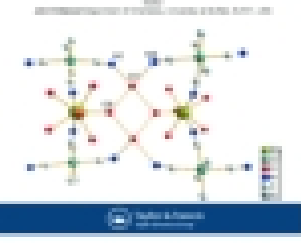

\title{
Mononuclear piano-stool iron 2- ethynylbenzo[b]thiophene complex: Crystal structure and reversible oxidation studied by spectro-electrochemical and DFT methods
}

\author{
Ya-Ping Ou, Jing Zhang, Daizhi Kuang, Fuxing Zhang, Jiangxi Yu, Xiaoming \\ Zhu, Sheng Hua Liu \& František Hartl
}

To cite this article: Ya-Ping Ou, Jing Zhang, Daizhi Kuang, Fuxing Zhang, Jiangxi Yu, Xiaoming Zhu, Sheng Hua Liu \& František Hartl (2017): Mononuclear piano-stool iron 2ethynylbenzo[b]thiophene complex: Crystal structure and reversible oxidation studied by spectro-electrochemical and DFT methods, Journal of Coordination Chemistry, DOI: 10.1080/00958972.2016.1278434

To link to this article: http://dx.doi.org/10.1080/00958972.2016.1278434

View supplementary material $\widetilde{ }$

Accepted author version posted online: 03

Jan 2017.

Submit your article to this journal $₫$

View related articles ๘

View Crossmark data 
Publisher: Taylor \& Francis

Journal: Journal of Coordination Chemistry

DOI: http://dx.doi.org/10.1080/00958972.2016.1278434

\title{
Mononuclear piano-stool iron 2-ethynylbenzo[b]thiophene complex: Crystal structure and reversible oxidation studied by spectro-electrochemical and DFT methods
}

\author{
YA-PING OU*†, JING ZHANG ${ }^{*}$, DAIZHI KUANG $\dagger$, FUXING ZHANG $\dagger$, JIANGXI YU $\dagger$, XIAOMING ZHU $\dagger$, \\ SHENG HUA LIU $\ddagger$ and FRANTIŠEK HARTL*§ \\ $†$ College of Chemistry and Material Science, Hengyang Normal University; Key Laboratory of Functional \\ Organometallic Materials of Hengyang Normal University, College of Hunan Province, Hengyang, \\ Hunan 421008, People's Republic of China \\ $\ddagger$ Key Laboratory of Pesticide and Chemical Biology, Ministry of Education, College of Chemistry, \\ Central China Normal University, Wuhan 430079, P.R. China \\ §Department of Chemistry, University of Reading, Whiteknights, Reading RG6 6AD, U.K.
}

A mononuclear iron complex with 2-ethynylbenzo[b]thiophene $C$-coordinated to the $\left(\eta^{5}-\mathrm{Cp} *\right)\left(\eta^{2}\right.$-dppe)Fe $\left(\mathrm{Cp}^{*}=\right.$ pentamethylcyclopentadienyl, dppe = 1,2-diphenylphosphinoethane $)$ framework (1) was prepared and characterized by ${ }^{1} \mathrm{H}-\mathrm{NMR}$, elemental analysis and single crystal X-ray diffraction. The redox behavior of 1 was investigated by voltammetric methods and anodic spectroelectrochemistry in the UV-vis-NIR-IR region and compared with reference complexes including 2-ferrocenylbenzo $[b]$ thiophene (2) and the 2-ethynylpyridine derivative of $\mathbf{1}$. The spin density distribution along the linear molecular backbone in $\mathbf{1}^{+}$was analyzed by DFT (BLYP35) and TDDFT calculations of a truncated model complex. The combined experimental and theoretical results revealed an important role of the ethynylene linker in determining the redox properties of this family of complexes and participation of the 2-ethynylbenzo[ $b]$ thiophene framework in the largely iron-based anodic electron transfer.

\footnotetext{
*Corresponding authors. Email: ouyaping123@126.com (Y-P. Ou); f.hartl@ reading.ac.uk (F. Hartl)
} 
Keywords: Benzo[b]thiophene; Iron cyclopentadienyl complex; Ethynylene linker; X-ray crystallography; Spectroelectrochemistry; Density Functional Theory

\section{Introduction}

Oligonuclear organometallic complexes featuring carbon-rich molecular bridges as linkers or components of redox-active centers have served as attractive objects in the field of molecular electronic devices by virtue of their versatile redox and magnetic properties [1-9]. In particular, redox-active iron derivatives linked to aromatic and heteroaromatic rings have served as suitable models in studies of electronic communication between metallic termini and screening of molecular wires [10-14]. For example, Lang [8, 15] and Iyoda [16] reported a series of heteroatomic multiferrocenyl species, using palladium-catalyzed C-C cross-coupling Negishi reaction, and studied their electronic coupling properties. In the past decade, Lapinte et al. $[6,11,17-19]$ also investigated electronic and magnetic properties of dinuclear complexes with redox-active half-sandwich $\mathrm{Cp}^{*}(\mathrm{dppe}) \mathrm{Fe}$ units. These studies reveal that electronic and spectroscopic properties of the metal complexes are determined by molecular bonding properties and the type of redox-active terminal groups. Mononuclear metal complexes with attached conjugated aromatic frameworks are often used as building blocks to afford multinuclear organometallic molecular wires [20-22], serving as references to unravel their electronic properties. Benzo[b]thiophene frameworks with a reactive $\alpha$-hydrogen in the thiophene ring and a peculiar electronic character have been applied widely in the field of materials chemistry and molecular electronics [23-25]. We describe herein the synthesis and molecular structure of 1 with benzo[b]thiophene-2-yl linked to the $\mathrm{Cp} *(\mathrm{dppe}) \mathrm{Fe}-\mathrm{C} \equiv \mathrm{C}$ - group (chart 1). Along with $\mathbf{1}$, we also synthesized the reference 2-ferrocenylbenzo[b]thiophene complex (2) to assess the impact of the ethynylene linker on the redox and bonding properties; meantime, 2 has been reported in the literature [9]. The anodic behavior of $\mathbf{1}$ was investigated in situ by cyclic voltammetry and spectroelectrochemical methods in the UV-vis-NIR and IR spectral regions. The electronic 
structure and molecular spectroscopic characteristics of stable monocation $\mathbf{1}^{+}$were further explored by DFT and TD-DFT calculations.

\section{Experimental}

\subsection{Materials and methods}

All manipulations were carried out under an atmosphere of dry argon by using standard Schlenk techniques, unless stated otherwise. Solvents were pre-dried, distilled and kept under an atmosphere of a dry inert gas (nitrogen or argon) prior to use in spectro-electrochemical measurements. Tetrabutylammonium hexafluorophosphate $\left(\mathrm{Bu}_{4} \mathrm{NPF}_{6}\right)$, used as a supporting electrolyte, was recrystallized twice from absolute ethanol and dried overnight under vacuum prior to electrochemical experiments. Trimethylsilylacetylene (TMSA), ferrocene, anhydrous zinc chloride, ${ }^{t} \mathrm{BuOK}, \mathrm{NaBPh}_{4},\left[\mathrm{Pd}\left(\mathrm{PPh}_{3}\right)_{4}\right], \mathrm{KF}$, solvents and $\mathrm{Bu}_{4} \mathrm{NPF}_{6}$ were purchased from Sinopharm Chemical Reagent Co., Ltd. and used without purification. The starting complex $[\mathrm{Cp} * \mathrm{Fe}(\mathrm{dppe}) \mathrm{Cl}]$ was prepared by a literature procedure [26].

Nuclear magnetic resonance (NMR) spectra were recorded on a Varian Mercury Plus 400 spectrometer $(400 \mathrm{MHz})$ operating at $298 \mathrm{~K}$ in the Fourier transform mode. ${ }^{1} \mathrm{H}$ - and ${ }^{13} \mathrm{C}-\mathrm{NMR}$ chemical shifts (ppm) are relative to TMS and ${ }^{31} \mathrm{P}$ NMR chemical shifts are relative to $85 \%$ $\mathrm{H}_{3} \mathrm{PO}_{4}$. Elemental analyses (C, $\mathrm{H}$ and $\mathrm{N}$ ) were performed with a Vario ElIII CHNS instrument.

Electrochemical data were obtained from cyclic voltammetry and square-wave voltammetry using a CHI 660C potentiostat (USA) and a standard air-tight three-electrode cell. The concentrations of the analyte $(\mathbf{1}$ and $\mathbf{2})$ and supporting electrolyte $\left(\mathrm{Bu}_{4} \mathrm{NPF}_{6}\right)$ were typically $10^{-3}$ and $10^{-1} \mathrm{~mol} \mathrm{dm}^{-3}$, respectively. A pre-polished $500-\mu \mathrm{m}$ diameter platinum disk working electrode, a platinum wire counter electrode, and an $\mathrm{Ag} / \mathrm{Ag}^{+}\left(10^{-2} \mathrm{M} \mathrm{AgNO}_{3}+10^{-1} \mathrm{M} \mathrm{Bu}_{4} \mathrm{NPF}_{6}\right.$ in acetonitrile) reference electrode were used; the standard ferrocene/ferrocenium $\left(\mathrm{Fc} / \mathrm{Fc}^{+}\right)$ couple was found at $E_{1 / 2}=0.21 \mathrm{~V}$ under these conditions. Spectroelectrochemical experiments at room temperature were performed with an air-tight optically transparent thin-layer electrochemical (OTTLE) cell (optical path length of $c a .200 \mu \mathrm{m}$ ) equipped with a Pt minigrid 
working electrode and $\mathrm{CaF}_{2}$ windows [27]. The cell was positioned in the sample compartments of a Bruker Tensor FT-IR spectrometer $\left(1 \mathrm{~cm}^{-1}\right.$ spectral resolution, 8 scans $)$ and a Shimadzu UV-3600 UV-vis-NIR spectrophotometer. The controlled-potential electrolyses within the OTTLE cell were carried out using a CHI 660C potentiostat.

DFT calculations were performed with Gaussian 09 [28] at the B3LYP/6-31G* and BLYP35 [29]/6-31G* levels of theory. Geometry optimizations were performed without any symmetry constraints, and frequency calculations on the resulting optimized geometries showed no imaginary frequencies. Electronic transitions were calculated by the time-dependent DFT (TD-DFT) method. The MO contributions were generated using the Multiwfn2.6.1_bin_Win package and plotted using Gauss View 5.0.

\subsection{Preparation of iron complexes}

\subsection{1. $\eta^{5}$-Pentamethylcyclopentadienyl $\eta^{2}$-1,2-diphenylphosphinoethane}

2-benzo[b]thiophenylethynyl iron(II) (1). A solution of 2-trimethylsilylethynylbenzo[b]thiophene [3, 30] (32 mg, $0.14 \mathrm{mmol})$ and $\mathrm{K}_{2} \mathrm{CO}_{3}(127 \mathrm{mg}, 2.20 \mathrm{mmol})$ in $\mathrm{CH}_{3} \mathrm{OH}(20 \mathrm{~mL})$ was heated to reflux under nitrogen for $10 \mathrm{~h}$. Then [Cp*Fe(dppe) $\mathrm{Cl}](0.5 \mathrm{~g}, 0.8 \mathrm{mmol}, 1.1$ equiv) and $\mathrm{Na}\left[\mathrm{BPh}_{4}\right]\left(274 \mathrm{mg}, 0.8 \mathrm{mmol}, 1.1\right.$ equiv) were added. After $12 \mathrm{~h}$ of stirring, ${ }^{t} \mathrm{BuOK}$ (100 mg, 1.1 equiv) was introduced, Stirring was maintained for an additional $4 \mathrm{~h}$ before the solvent was removed. The residue was extracted with toluene $(4 \times 20 \mathrm{~mL})$, and the solution was concentrated to $c a .4 \mathrm{~mL}$. Addition of pentane $(40 \mathrm{~mL})$ led to precipitation of a dark red powder. The solid was washed with pentane $(5 \times 10 \mathrm{~mL})$ and dried to give $\mathbf{1}$. Crystals of $\mathbf{1}$ suitable for X-ray analysis were grown from dichloromethane upon slow diffusion of hexane. Yield of red brown crystals: $80 \mathrm{mg}, 72 \% .{ }^{1} \mathrm{H}$ NMR (400 MHz, $\left.\mathrm{CDCl}_{3}\right): \delta 1.42\left(\mathrm{~s}, 15 \mathrm{H}, \mathrm{C}_{5}\left(\mathrm{CH}_{3}\right)_{5}\right), 1.99(\mathrm{br}, 2 \mathrm{H}$, $\mathrm{CH}_{2 / \mathrm{dppe}}$ ), 2.63 (br, $\left.2 \mathrm{H}, \mathrm{CH}_{2 / \mathrm{dppe}}\right), 6.52(\mathrm{~s}, 1 \mathrm{H}$, thiophene ring), $7.10(\mathrm{t}, J(\mathrm{HH})=7.2 \mathrm{~Hz}, 1 \mathrm{H}$, benzene ring), $7.19\left(\mathrm{t}, J(\mathrm{HH})=7.2 \mathrm{~Hz}, 1 \mathrm{H}\right.$, benzene ring), 7.26-7.38 $\left(\mathrm{m}, 16 \mathrm{H}, \mathrm{H}_{\mathrm{Ar} / \mathrm{dppe}}\right), 7.47(\mathrm{~d}$, $J(\mathrm{HH})=3.6 \mathrm{~Hz}, 1 \mathrm{H}$, benzene ring $), 7.55(\mathrm{~d}, J(\mathrm{HH})=4.4 \mathrm{~Hz}, 1 \mathrm{H}$, benzene ring), 7.80-7.89 (m, 
4H, $\left.\mathrm{H}_{\text {Ar/dppe }}\right){ }^{31} \mathrm{P}$ NMR $\left(160 \mathrm{MHz}, \mathrm{CDCl}_{3}\right): \delta 96.51$ (s, dppe). IR $\left(\mathrm{KBr} / \mathrm{cm}^{-1}\right): v(\mathrm{C} \equiv \mathrm{C}) 2034(\mathrm{w})$. Anal. Calcd. for $\mathrm{C}_{46} \mathrm{H}_{44} \mathrm{P}_{2} \mathrm{FeS}(\%)$ : C, 73.99; H, 5.94. Found: C, 74.10; H, 5.76.

2.2.2. 2-Ferrocenylbenzo[b]thiophene (2). The complex was prepared following a slightly modified procedure reported by Santi et al. [9] having used $\left[\mathrm{Pd}\left(\mathrm{PPh}_{3}\right)_{4}\right]$ as catalyst instead of $\left[\mathrm{PdCl}_{2}\left(\mathrm{PPh}_{3}\right)_{2}\right] .{ }^{1} \mathrm{H}$ NMR (400 MHz, $\left.\mathrm{CDCl}_{3}\right): \delta 4.12\left(\mathrm{~s}, 5 \mathrm{H}, \mathrm{C}_{5} \mathrm{H}_{5}\right), 4.35$ (s, 2H, $\left.\mathrm{C}_{5} \mathrm{H}_{4}\right), 4.67$ (s, $\left.2 \mathrm{H}, \mathrm{C}_{5} \mathrm{H}_{4}\right), 7.21(\mathrm{~s}, 1 \mathrm{H}$, thiophene), $7.30(\mathrm{t}, J(\mathrm{HH})=8.4 \mathrm{~Hz}, 1 \mathrm{H}), 7.32(\mathrm{t}, J(\mathrm{HH})=7.6 \mathrm{~Hz}, 1 \mathrm{H})$, $7.66(\mathrm{~d}, J(\mathrm{HH})=4.4 \mathrm{~Hz}, 1 \mathrm{H}), 7.76(\mathrm{~d}, J(\mathrm{HH})=3.6 \mathrm{~Hz}, 1 \mathrm{H}) .{ }^{13} \mathrm{C} \mathrm{NMR}\left(100 \mathrm{MHz}, \mathrm{CDCl}_{3}\right)$ : $\delta 67.3(\mathrm{Fc}), 69.2(\mathrm{Fc}), 70.1(\mathrm{Fc}), 79.4(\mathrm{Fc}), 117.9,122.0,122.6,123.5,124.3,139.1,140.6,143.9$. Anal. Calcd. for $\mathrm{C}_{18} \mathrm{H}_{14} \mathrm{FeS}(\%)$ : C, 67.94; H, 4.43. Found: C, 67.76; H, 4.49.

\subsection{Single crystal $X$-ray crystallography}

Single crystals of 1 suitable for X-ray diffraction were obtained by slow diffusion of hexane into a dichloromethane solution containing 1 at room temperature. A crystal of approximate dimensions $0.12 \times 0.10 \times 0.10$ (in $\mathrm{mm}$ ) was mounted on a glass fiber for diffraction experiments. Intensity data were collected on a Nonius Kappa CCD diffractometer with $\mathrm{Mo} \mathrm{K}_{\alpha}$ radiation $(\lambda=$ $0.71073 \AA$ ) at room temperature. Data reduction was carried out using the SAINT-NT software package [31]. Multi-scan absorption corrections were applied to all intensity data using SADABS [32]. The molecular structure was solved by a combination of direct methods and Fourier difference techniques, and refined by full matrix least squares (SHELXL-97) [33]. All non-H atoms were refined anisotropically. Hydrogens were placed in ideal positions and refined as riding. Crystal parameters and details of the data collection are summarized in table 1.

\section{Results and discussion}

\subsection{Synthesis and crystallography}

Complex 1 was prepared from precursor $\mathbf{1 b}$ (scheme 1) described in the literature [3, 30]. A subsequent straightforward three-step procedure gave $\mathbf{1}$ in high yield. Complex $\mathbf{2}$ was 
synthesized by the classical palladium-catalyzed Negishi $\mathrm{C}-\mathrm{C}$ cross-coupling reaction, following a slightly modified procedure to that reported in the literature [9]. Complex $\mathbf{1}$ was characterized by ${ }^{1} \mathrm{H}$ NMR spectroscopy (Supporting Information, figure S1), elemental analysis and single crystal X-ray diffraction. The ${ }^{13} \mathrm{C}$ NMR spectrum of $\mathbf{1}$ was complicated by signal broadening caused either by minor paramagnetic (Fe(III)) impurities from the synthetic procedure or by spin-crossover effects at room temperature.

Single crystal X-ray diffraction elaborated further the solid state structure of 1 (figure 1). In the process of crystal refinement, we dealt with disorder of the thiophene ring (S1, C45 and C46) by setting free variable refinements, and the ratio of the occupancy of two disordered components is 0.41/0.59 (figure S2) (Supporting Information). We carried out DFT-optimized calculations with both of the disordered structures of $\mathbf{1}$ and obtained the same results. Selected bond lengths $(\AA)$ and angles (deg) from the crystal structure of 1 and the DFT-optimized structures $[\mathbf{1 - H}]^{n+}(n=0,1)$ are listed in table 2. The extension '- $\mathrm{H}$ ' indicates that $\eta-\mathrm{C}_{5} \mathrm{Me}_{5}$ and dppe ligands in $\mathbf{1}$ were replaced by $\eta^{5}-\mathrm{C}_{5} \mathrm{H}_{5}$ and two $\mathrm{PH}_{3}$ ligands, respectively. Viewing from figure 1, 1 exhibits a pseudotetrahedral piano-stool geometry of related iron complexes $[6,18,19]$. Bond lengths $\mathrm{Fe}(1)-\mathrm{C}(37)(1.883 \AA)$ and $\mathrm{C}(37)-\mathrm{C}(38)(1.226 \AA)$ represent the iron-ethynyl unit; the corresponding bonds in model [1-H] from the DFT-optimized structure are slightly longer. Bond angles $\mathrm{C}(37)-\mathrm{C}(38)-\mathrm{C}(46)$ and $\mathrm{Fe}(1)-\mathrm{C}(37)-\mathrm{C}(38)$ of $174.84^{\circ}$ and $178.23^{\circ}$, respectively, mark the linear iron $-\mathrm{C}_{\alpha}-\mathrm{C}_{\beta}$ (ethynylene) $-\mathrm{C}_{\gamma}$ (benzothiophene) backbone in $\mathbf{1}$ and are in close proximity to the corresponding values calculated for $[\mathbf{1 - H}]$. The model complex has stronger $\pi$-conjugation along the molecular backbone due to a greater conformational freedom at iron. Compared with the crystal structure of 2-ferrocenylbenzo[b]thiophene (2) [9], the bond lengths in the benzo[b]thiophene skeleton exhibit small differences. The $\mathrm{C}-\mathrm{S}$ bond in $\mathbf{1}$ is longer than that in 2 , and the $\mathrm{C}-\mathrm{C}$ bonds linking the benzo[b]thiophene moiety with the ferrocenyl and $\left(\eta^{5}-\mathrm{Cp} *\right)\left(\eta^{2}\right.$-dppe $) \mathrm{Fe}-\mathrm{C} \equiv \mathrm{C}$ terminals also display small differences, which can be attributed to orientation and conjugation effects. The dinuclear iron complex with 2,6-bis(ethynyl)pyridine spanning the same terminal groups [19] shows a $C \equiv C$ bond length of $1.219 \AA$, which is slightly 
shorter compared to $1.226 \AA$ in $\mathbf{1}$, in line with the less negative oxidation potential of the latter complex (see below) caused by the withdrawing nature of the benzothiophene system.

Oxidation of model complex $[\mathbf{1 - H}]$ to $[\mathbf{1 - H}]^{+}$caused elongation of the $\mathrm{Fe}(1)-\mathrm{P}(1,2)$ and $\mathrm{C}(37)-\mathrm{C}(38)$ bonds, along with a decrease of the $\mathrm{Fe}(1)-\mathrm{C}(37)$ bond length and the $\mathrm{P}(1)-\mathrm{Fe}(1)-\mathrm{P}(2)$ bond angle (table 2). These structural changes clearly indicate that the one-electron oxidation of $[\mathbf{1 - H}]$ is strongly localized on the iron-ethynyl moiety, with some participation of the terminal benzothiophene unit.

\subsection{Electrochemistry}

The anodic response of $\mathbf{1}$ was investigated by cyclic voltammetry (CV) and square-wave voltammetry (SWV) in $\mathrm{CH}_{2} \mathrm{Cl}_{2} / \mathrm{Bu}_{4} \mathrm{NPF}_{6}$. Both 1 and 2 exhibit a reversible anodic wave (figure 2). The $E_{1 / 2}$ value determined for 1 is lower by $0.56 \mathrm{~V}$ compared to 2 (table 3 ). The HOMO of 2 has been shown to reside $74 \%$ on Fe [9] with the withdrawing effect of the benzo $[b]$ thiophene-2-yl substituent increasing the potential of the ferrocene oxidation. In contrast, the HOMO of $\mathbf{1}$ is strongly delocalized over the $\pi$-conjugated Fe-ethynyl-benzothiophene backbone (see the Crystallography and DFT sections for support). The negative oxidation potential ( $v s \mathrm{Fc} / \mathrm{Fc}^{+}$) of benzo[b] thiophene-2-yl complex 1 nicely corresponds with similar values reported in the literature [19] for the phenyl and 2-pyridyl derivatives (table 3), proving the key role of the ethynylene linker in determining the redox properties of this family of complexes (see the IR SEC section below).

\subsection{UV-vis-NIR and IR spectroelectrochemistry}

UV-vis-NIR (figure 3) and IR (figure 4) spectroelectrochemcial monitoring of the reversible oxidation of $\mathbf{1}$ and $\mathbf{2}$ to the corresponding cations was carried out with an optically transparent thin-layer electrochemical (OTTLE) cell under dry conditions.

Both 1 and 2 exhibit strong, presumably $\pi-\pi^{*}$ absorption in the UV spectral region, with maxima at $387 \mathrm{~nm}$ and $303 \mathrm{~nm}$, respectively. In addition, 2 features a weak MLCT absorption at 
$457 \mathrm{~nm}$ [9]. The oxidation to monocations $\mathbf{1}^{+}$and $\mathbf{2}^{+}$results in the appearance of a broad band at $788 \mathrm{~nm}$ for $\mathbf{1}^{+}$and $942 \mathrm{~nm}$ for $\mathbf{2}^{+}$(table 4). The visible absorption of $\mathbf{2}^{+}$is broader and weaker than that of $\mathbf{1}^{+}$(figure 3 ). The UV-vis-NIR absorption spectrum recorded for $\mathbf{2}^{+}$after anodic electrolysis agrees with that obtained after the chemical oxidation of $\mathbf{2}$ with acetylferrocenium [9]; the assignment of the visible-NIR absorption of $\mathbf{2}^{+}$as a benzo[b]thiophene-to-iron(III) charge transfer (LMCT) has been reported. The visible absorption of $\mathbf{1}^{+}$(table 4 ) has a strongly mixed ILCT/LMCT character, as revealed by TD-DFT calculations (see below).

IR spectral monitoring showed that the $v(C \equiv C)$ band of 1 at $2033 \mathrm{~cm}^{-1}$ shifted to $1967 \mathrm{~cm}^{-1}$ upon oxidation to $\mathbf{1}^{+}$(figure 4), implying an increased contribution of the $\mathrm{Fe}=\mathrm{C}=\mathrm{C}$ mesomeric form to the molecular backbone structure and significant participation of the ethynylene linker in the anodic electron transfer, in agreement with the structural analysis of $[\mathbf{1 - H}]^{+}($table 2).

\subsection{DFT and TD-DFT calculations}

To describe the nature of the one-electron oxidation of $\mathbf{1}$ and determine the electronic structure of the stable cationic product in greater detail, corresponding model complexes $[\mathbf{1 - H}]$ and $[\mathbf{1 - H}]^{+}$ with dppe and $\mathrm{Cp}^{*}$ in the half-sandwich unit replaced by two $\mathrm{PH}_{3}$ ligands and $\mathrm{Cp}$ [4] were selected to perform density functional theory (DFT) calculations at the B3LYP/6-31G* and BLYP35/6-31G* levels.

First we have calculated the $v(\mathrm{C} \equiv \mathrm{C})$ frequencies for $[\mathbf{1 - H}]$ and $[\mathbf{1 - H}]^{+}$: the values of 2174 and $2065 \mathrm{~cm}^{-1}$ (with B3LYP), and 2448 and $2388 \mathrm{~cm}^{-1}$ (with BLYP35), respectively, document that the red shift of $\Delta \tilde{v}=64 \mathrm{~cm}^{-1}$ obtained with the BLYP35 method is very close to the experimentally determined difference, $\Delta \tilde{v}=66 \mathrm{~cm}^{-1}$ (figure 4). Spin densities in [1-H $]^{+}$(figure 5) calculated with both DFT methods are distributed along the whole linear molecular backbone (figure 1). However, the dominant $70 \%$ contribution from the Fe center revealed by BLYP35 (figure 5b) is much larger than the 58\% obtained with B3LYP (figure 5a). The BLYP35 values 
are consistent with the spin density data published for the reference cationic mononuclear 2-ethynylpyridine complex [34] that also shows a similar oxidation potential to 1 (table 3).

The visible electronic absorption spectrum of $\mathbf{1}^{+}$has been assigned on the grounds of TD-DFT calculations of $[\mathbf{1 - H}]^{+}$with the more rational BLYP35 method that has successfully reproduced the $v(\mathrm{C} \equiv \mathrm{C})$ wavenumber change upon oxidation of $\mathbf{1}$ residing dominantly at the Fe center. Cation $[\mathbf{1 - H}]^{+}$features an intense electronic absorption at $784 \mathrm{~nm}\left(12800 \mathrm{~cm}^{-1}\right)$ and a weaker one at $538 \mathrm{~nm}\left(18600 \mathrm{~cm}^{-1}\right)$. The calculated data including the oscillator strength (table 5) are indeed in excellent agreement with the observed electronic absorption of $\mathbf{1}^{+}$in the $500-900 \mathrm{~nm}$ range (figure 3a, table 4). Both optical excitations are dominated by the $\beta$-HOSO $\rightarrow \beta$-LUSO transition (figure 6) exhibiting a 2-ethynylbenzothiophene-to-Fe(III) charge transfer (LMCT) character. Another LMCT transition, viz. $\beta$-HOSO-1 $\rightarrow \beta$-LUSO, contributes to the electronic absorption in the green light spectral region. On the other hand, the lowest energy (red light) absorption also encompasses the $\alpha$-HOSO $\rightarrow \alpha-$ LUSO +2 transition corresponding to an intraligand, $\pi \rightarrow \pi^{*}$ (2-ethynylthiophene based) excited state.

\section{Conclusion}

DFT and TD-DFT calculations of model $[\mathbf{1 - H}]^{+}$with the BLYP35/6-31G* method have reproduced the significant decrease in the $v(C \equiv C)$ frequency recorded in the reversible oxidation of $\left[\mathrm{Cp}^{*} \mathrm{Fe}(\mathrm{dppe})(2\right.$-ethynylbenzo[b]thiophene)] (1) to the corresponding cation along with the visible electronic absorption of the oxidized complex. The distribution of the spin density in $\mathbf{1}^{+}$ can be presented as largely localized $(c a .70 \%)$ at the iron center. In this regard $\mathbf{1}^{+}$closely resembles the reference iron complex with 2-ethynylpyridine bound to the half-sandwich moiety [34]. It is therefore not surprising that both complexes feature very similar oxidation potentials [19]. The accentuated contribution of the $\mathrm{Fe}=\mathrm{C}=\mathrm{C}=$ mesomeric structure of the ethynylene linker in the linear molecular backbone of the oxidized complexes ensures distribution of the spin density also over the conjugated heterocyclic (benzothiophene, pyridine) termini. This electronic communication is probably emphasized in the ruthenium derivative of $\mathbf{1}(\mathrm{Ru}-\mathbf{1})$ [35] where the 
one-electron oxidation causes a larger red shift of the $v(C \equiv C)$ frequency $\left(66 \mathrm{~cm}^{-1}\right.$ for 1 vs $77 \mathrm{~cm}^{-1}$ for Ru-1). The oxidation potential of Ru-1 is shifted significantly less negatively by $410 \mathrm{mV}$ compared to 1, which may signal stronger participation of the terminal benzothiophene. Varying the transition metal center in this family of complexes therefore has a higher impact on the HOMO energy than different conjugated termini at the ethynylene linker, as expected for the largely metal-based oxidation.

The other reference complex 2-ferrocenylbenzo[b]thiophene (2) [9] conyerts upon one-electron oxidation almost exclusively to the ferrocenium product $\left(\mathbf{2}^{+}\right)$. Despite lacking the ethynylene linker in $\mathbf{2}^{+}$, both formally $\mathrm{Fe}$ (III) cationic complexes feature similar electronic absorption in the visible spectral region assigned to benzothiophene-to-iron charge transfer (LMCT) transitions. The lowest-energy LMCT absorption of $\mathbf{1}^{+}$(with a sizable $\pi-\pi^{*}$ intraligand component) exhibits much higher intensity compared to that of $\mathbf{2}^{+}$, which may reasonably be attributed to participation of the ethynylene linker mediating the charge transfer to the iron center and facilitating its interaction with terminal benzothiophene.

\section{Supplementary material}

The ${ }^{1} \mathrm{H}$ NMR spectrum and molecular structure of $\mathbf{1}$ with fully labeled thermal ellipsoid plot (50\% level). CCDC 1443689 contains the supplementary crystallographic data for $\mathbf{1}$. These data can be obtained free of charge from the Cambridge Crystallographic Data Centre via www.ccdc.cam.ac.uk/data_request/cif.

\section{Acknowledgements}

The authors acknowledge financial support from the Opening Subjects of Hunan Province Key Laboratory of Functional Organometallic Materials (Grant No. GN15K05) and the Scientific Research Foundation of the Hengyang Normal University (Grant No. 14B23). The theoretical calculations and spectroelectrochemistry were conducted in the Department of Chemistry at the 
Central China Normal University. F.H. thanks the University of Reading for the continued support of the Reading Spectroelectrochemistry laboratory (Project D14-015).

\section{References}

[1] P. Aguirre-Etcheverry, D. O'Hare. Chem. Rev., 110, 4839 (2010).

[2] C.-J. Yao, Y.-W. Zhong, J. Yao. J. Am. Chem. Soc., 133, 15697 (2011).

[3] Y.-P. Ou, J. Xia, J. Zhang, M. Xu, J. Yin, G.-A. Yu, S.H. Liu. Chem. Asian J., 8, 2023 (2013).

[4] M.A. Fox, B.L. Guennic, R.L. Roberts, D.A. Brue, D.S. Yufit, J.A.K. Howard, G. Manca, J.-F. Halet, F. Hartl, P.J. Low. J. Am. Chem. Soc., 133, 18433 (2011).

[5] P. Debroy, S. Roy. Coord. Chem. Rev., 251, 203 (2007).

[6] C. Lapinte. J. Organomet. Chem., 693, 793 (2008).

[7] L.-B. Gao, J. Kan, Y. Fan, L.-Y. Zhang, S.-H. Liu, Z.-N. Chen. Inorg. Chem., 46, 5651 (2007).

[8] A. Hildebrandt, H. Lang. Organometallics, 32, 5640 (2013).

[9] A. Donoli, A. Bisello, R. Cardena, M. Crisma, L. Orian, S. Santi. Organometallics, 34, $4451(2015)$.

[10] K. Venkatasubbaiah, A. Doshi, I. Nowik, R.H. Herber, A.L. Rheingold, F. Jäkle. Chem. Eur. J., 14, 444 (2008).

[11] P. Hamon, F, Justaud, O. Cador, P. Hapiot, S. Rigaut, L. Toupet, L. Ouahab, H. Stueger, J. Hamon, C. Lapinte. J. Am. Chem. Soc., 130, 17372 (2008).

[12] G. Grelaud, O. Cador, T. Roisnel, G. Argouarch, M.P. Cifuentes, M.G. Humphrey, F. Paul. Organometallics, 31, 1635 (2012).

[13] F. Malvolti, C. Rouxel, A. Triadon, G. Grelaud, N. Richy, O. Mongin, M. Blanchard-Desce, L. Toupet, F.I. Abdul Razak, R. Stranger, M. Samoc, X. Yang, G. Wang, A. Barlow, M.P. Cifuentes, M.G. Humphrey, F. Paul. Organometallics, 34, $5418(2015)$ 
[14] U. Pfaff, A. Hildebrandt, M. Korb, D. Schaarschmidt, M. Rosenkranz, A. Popov, H. Lang. Organometallics, 34, 2826 (2015).

[15] D. Miesel, A. Hildebrandt, M. Korb, D. Schaarschmidt, H. Lang. Organometallics, 34, 4293 (2015).

[16] M. Iyoda, T. Kondo, T. Okabe, H. Matsuyama, S. Sasaki, Y. Kuwatani. Chem. Lett., 26, 35 (1997).

[17] R. Makhoul, H. Sahnoune, V. Dorcet, J.-F. Halet, J.-R. Hamon, C. Lapinte. Organometallics, 34, 3314 (2015).

[18] A. Burgun, F. Gendron, T. Roisnel, S. Sinbandhit, K. Costuas, J-F Halet, M.I. Bruce, C. Lapinte. Organometallics, 32, 1866 (2013).

[19] K. Costuas, O. Cador, F. Justaud, S.L. Stang, F. Paul, A. Monari, S. Evangelisti, L. Toupet, C. Lapinte, J.-F. Halet. Inorg. Chem., 50, 12601 (2011).

[20] M.-C. Oerthel, D.S. Yufit, M.A. Fox, M.R. Bryce, P.J. Low. Organometallics, 34, 2395 (2015).

[21] R. Sakamoto, T. Kambe, S. Tsukada, K. Takada, K. Hoshiko, Y. Kitagawa, M. Okumura, H. Nishihara. Inorg. Chem., 52, 7411 (2013).

[22] F. Lissel, T. Fox, O. Blacque, W. Polit, R.F. Winter, K. Venkatesan, H. Berke. J. Am. Chem. Soc., 135, 4051 (2013).

[23] Z. Pan, Y. Liu, F. Fan, Y. Chen, Y. Li, X. Zhan, Y. Song. Chem. Eur. J., 19, 9771 (2013).

[24] C.S. Smithson, Y. Wu, T. Wigglesworth, S. Zhu. Adv. Mater., 27, 228 (2015).

[25] Y.-P. Ou, J.Zhang, F.-X. Zhang, D.-Z. Kuang, F. Hartl, L. Rao, S.H. Liu. Dalton Trans., 45, 6503 (2016).

[26] C. Roger, P. Hamon, L. Toupet, H. Rabaa, J.Y. Saillard, J.-R. Hamon, C. Lapinte. Organometallics, 10, 1045 (1991).

[27] M. Krejčík, M. Daněk, F. Hartl. J. Electroanal. Chem., Interfacial Electrochem., 317, 179 (1991). 
[28] Gaussian 09, Revision D.01, M.J. Frisch, G.W. Trucks, H.B. Schlegel, G.E. Scuseria, M.A. Robb, J.R. Cheeseman, G. Scalmani, V. Barone, B. Mennucci, G.A. Petersson, H. Nakatsuji, M. Caricato, X. Li, H.P. Hratchian, A.F. Izmaylov, J. Bloino, G. Zheng, J.L. Sonnenberg, M. Hada, M. Ehara, K. Toyota, R. Fukuda, J. Hasegawa, M. Ishida, T. Nakajima, Y. Honda, O. Kitao, H. Nakai, T. Vreven, J.A. Montgomery, Jr., J.E. Peralta, F. Ogliaro, M. Bearpark, J.J. Heyd, E. Brothers, K.N. Kudin, V.N. Staroverov, R.

Kobayashi, J. Normand, K. Raghavachari, A. Rendell, J.C. Burant, S.S. Yyengar, J. Tomasi, M. Cossi, N. Rega, J.M. Millam, M. Klene, J.E. Knox, J.B. Cross, V. Bakken, C. Adamo, J. Jaramillo, R. Gomperts, R.E. Stratmann, O. Yazyev, A.J. Austin, R. Cammi, C. Pomelli, J.W. Ochterski, R.L. Martin, K. Morokuma, V.G. Zakrzewski, G.A. Voth, P. Salvador, J.J. Dannenberg, S. Dapprich, A.D. Daniels, Ö. Farkas, J.B. Foresman, J.V. Ortiz, J. Cioslowski, D.J. Fox, Gaussian, Inc., Wallingford, CT (2009).

[29] M. Renz, K. Theilacker, C. Lambert, M. Kaupp. J. Am. Chem. Soc., 131, 16292 (2009).

[30] K. Krajewski, Y. Zhang, D. Parrish, J. Deschamps, P.P. Rollera, V.K. Pathakb. Bioorg. Med. Chem. Lett., 16, 3034 (2006).

[31] Bruker. SAINT-plus and APEX2. Bruker AXS Inc., Madison, Wisconsin, USA (2007).

[32] G.M. Sheldrick. SADABS, University of Göttingen, Germany (1996).

[33] G.M. Sheldrick Acta Crystallogr., 64, 112 (2008).

[34] F. Paul, F. Malvolti, G. da Costa, S. Le Stang, F. Justaud, G. Argouarch, A. Bondon, S. Sinbandhit, K. Costuas, L. Toupet, C. Lapinte. Organometallics, 29, 2491 (2010).

[35] Y.-P. Ou, J.Zhang, D.-Z. Kuang, F-X. Zhang, J.-X. Yu, X.-M. Zhu. Chin. J. Inorg. Chem., 32, 641(2016). 
Table 1. Crystallographic data and refinement details for $\mathbf{1 .}$

\begin{tabular}{|c|c|}
\hline Formula & $\mathrm{C}_{46} \mathrm{H}_{44} \mathrm{FeP}_{2} \mathrm{~S}$ \\
\hline FW & 746.66 \\
\hline Temperature & $100(2) \mathrm{K}$ \\
\hline Wavelength & $0.71073 \AA$ \\
\hline Crystal system & Orthorhombic \\
\hline Space group & Pbca \\
\hline$a(\AA)$ & $11.0315(10)$ \\
\hline$b(\AA)$ & $20.1820(18)$ \\
\hline$c(\AA)$ & $33.601(3)$ \\
\hline$\alpha\left(^{\circ}\right)$ & 90 \\
\hline$\beta\left(^{\circ}\right)$ & 90 \\
\hline$\gamma\left(\left(^{\circ}\right)\right.$ & 90 \\
\hline$V\left(\AA^{3}\right)$ & $7480.8(11)$ \\
\hline$Z$ & \\
\hline$D($ calc $)\left(\mathrm{mg} / \mathrm{m}^{3}\right)$ & 1.326 \\
\hline Abs. coeff. $\left(\mathrm{mm}^{-1}\right)$ & 0.577 \\
\hline$F(000)$ & 3136 \\
\hline Crystal size $\left(\mathrm{mm}^{3}\right)$ & $0.12 \times 0.10 \times 0.10$ \\
\hline$\theta$ range $\left(^{\circ}\right)$ & 1.21 to 26.00 \\
\hline Index ranges & $-13 \leq h \leq 13,-24 \leq k \leq 21,-41 \leq l \leq 41$ \\
\hline Reflections collected & 49926 \\
\hline Independent reflect. & $7363[R(\mathrm{int})=0.0982]$ \\
\hline Data/restr. 1 param. & $7363 / 49 / 508$ \\
\hline Goodness-of-fit on $F^{2}$ & 1.052 \\
\hline Final $R$ indices $[I>2 \sigma(I)]$ & $R 1=0.0371, w R 2=0.0936$ \\
\hline$R$ indices (all data) & $R 1=0.0455, w R 2=0.0977$ \\
\hline Diff. peak and hole $\left(\mathrm{e} . \AA^{-3}\right)$ & 0.503 and -0.382 \\
\hline
\end{tabular}


Table 2. Selected bond lengths ( $\AA$ ) and angles (deg) from crystal structure of $\mathbf{1}$ and the DFT-optimized structures of $[\mathbf{1}-\mathbf{H}]^{n+}(n=0,1)$.

\begin{tabular}{llll}
\hline & $\mathbf{1}$ & {$[\mathbf{1 - H}]$} & {$[\mathbf{1 - H}]^{+}$} \\
\hline $\mathrm{Fe}(1)-\mathrm{P}(1,2)$ & $2.175,2.184$ & $2.206,2.206$ & $2.245,2.245$ \\
$\mathrm{Fe}(1)-\mathrm{C}(37)$ & 1.883 & 1.910 & 1.840 \\
$\mathrm{C}(37)-\mathrm{C}(38)$ & 1.226 & 1.233 & 1.246 \\
$\mathrm{C}(38)-\mathrm{C}(46)$ & 1.423 & 1.407 & 1.386 \\
$\mathrm{C}(46)-\mathrm{C}(45)$ & 1.412 & 1.373 & 1.393 \\
$\mathrm{C}(46)-\mathrm{S}(1)$ & 1.697 & 1.785 & 1.777 \\
$\mathrm{P}(1)-\mathrm{Fe}(1)-\mathrm{P}(2)$ & 86.00 & 95.98 & 93.35 \\
$\mathrm{Fe}(1)-\mathrm{C}(37)-\mathrm{C}(38)$ & 178.23 & 178.84 & 179.74 \\
$\mathrm{C}(37)-\mathrm{C}(38)-\mathrm{C}(46)$ & 174.84 & 179.50 & 179.76 \\
\hline
\end{tabular}


Table 3. Electrochemical oxidation of $\mathbf{1}$ and reference compounds.

\begin{tabular}{llll}
\hline Complex & $E_{1 / 2}(\mathrm{~V})^{a}$ & $\Delta E_{\mathrm{p}}(\mathrm{mV})$ & $E_{\mathrm{p}}(\mathrm{V})^{b}$ \\
\hline $\mathbf{1}$ & -0.51 & 100 & -0.51 \\
$\mathbf{2}$ & $0.06^{c}$ & $100^{c}$ & 0.06 \\
& $0.06^{d, e}$ & 62 & \\
{$[\mathrm{Cp} *(\mathrm{dppe}) \mathrm{Fe}-\mathrm{C} \equiv \mathrm{C}-\mathrm{Ph}]^{f}$} & $-0.61^{e}$ & 80 & -- \\
{$[\mathrm{Cp} *(\mathrm{dpp}) \mathrm{Fe}-\mathrm{C} \equiv \mathrm{C}-(2-\mathrm{Py})]^{f}$} & $-0.54^{e}$ & 90 & --
\end{tabular}

${ }^{a}$ Cyclic voltammetry. Electrode potentials in volts $v s \mathrm{Fc} / \mathrm{Fc}^{+}$obtained at $298 \mathrm{~K}$ in dichloromethane $/ 10^{-1} \mathrm{M} \mathrm{Bu}_{4} \mathrm{NPF}_{6} .{ }^{b}$ Square wave voltammetry. ${ }^{c}$ This work. ${ }^{d}$ Ref. [9]. ${ }^{e}$ The reported values of $E_{1 / 2}$ determined against SCE were converted using $E_{1 / 2}\left(\mathrm{Fc} / \mathrm{Fc}^{+}\right)=0.46 \mathrm{~V}$ vs SCE in dry dichloromethane. ${ }^{f} \mathrm{Ref} .[19](\mathrm{Ph}=$ phenyl; 2-Py = 2-pyridyl). 
Table 4. UV-vis-NIR absorption data for $\mathbf{1}^{n+}$ and $\mathbf{2}^{n+}(n=0,1){ }^{a}$

\begin{tabular}{ll}
\hline Complex & $\begin{array}{l}\lambda_{\max }(\mathrm{nm}) \\
\left(\varepsilon_{\max }\left(\mathrm{dm}^{3} \mathrm{~mol}^{-1} \mathrm{~cm}^{-1}\right)\right)\end{array}$ \\
\hline $\mathbf{1}$ & $277(41900), 387(21200)$ \\
$\mathbf{1}^{+}$ & $367(11600), 422(9700), 516(2100), 788(8300)$ \\
$\mathbf{2}$ & $303(28900), 457(1100)$ \\
$\mathbf{2}^{+}$ & $395(8700), 465(4900), 942(1600)$ \\
\hline${ }^{a}$ In dichloromethane/Bu $4 \mathrm{NPF}_{6}$ at $293 \mathrm{~K}$.
\end{tabular}


Table 5. Major electronic excitations in model complex $[\mathbf{1 - H}]^{+}$determined by the TD-DFT method (BLYP35 /6-31G*).

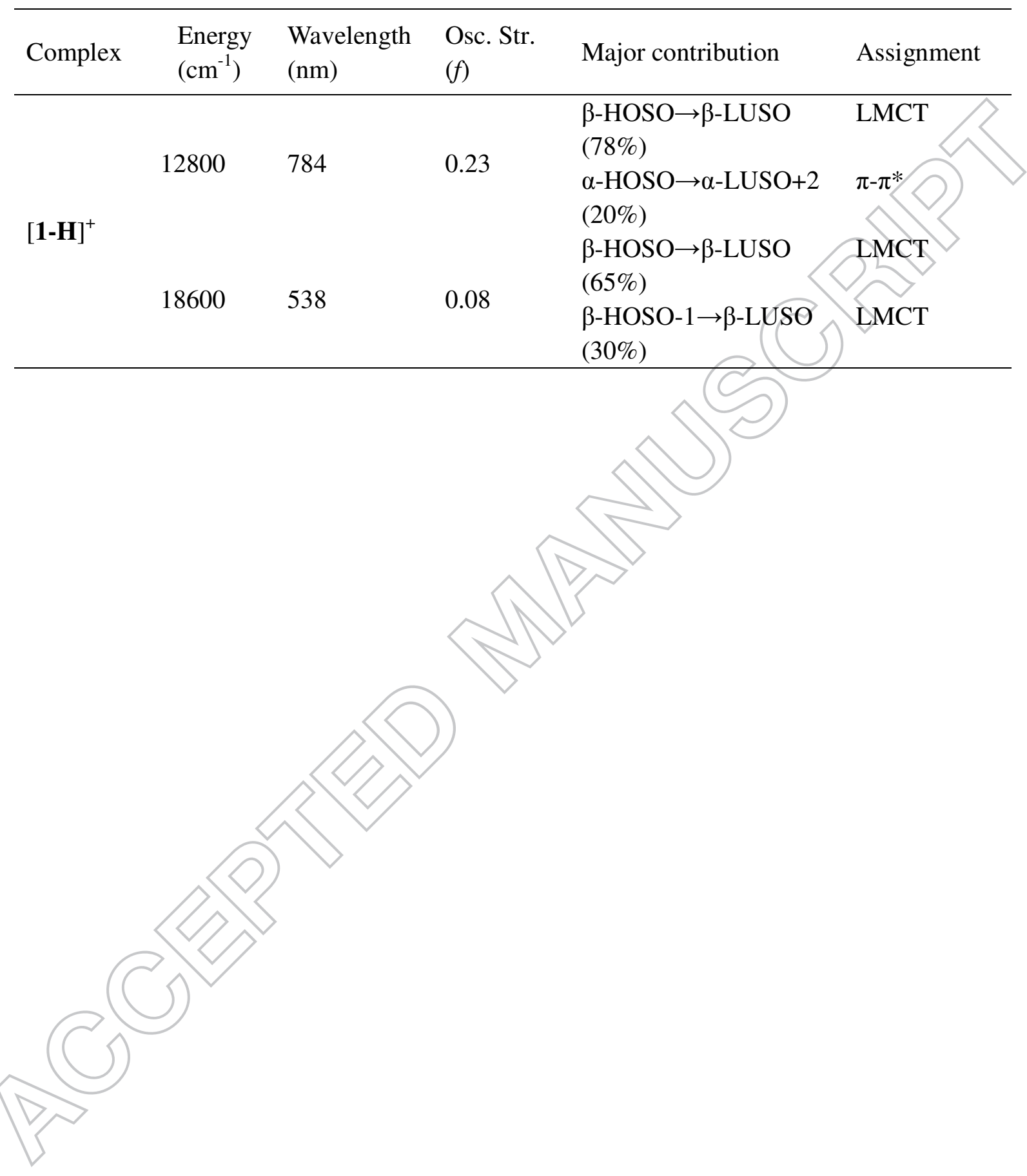


紧年

1
(2)

2 
TMSA

促

1a

1b

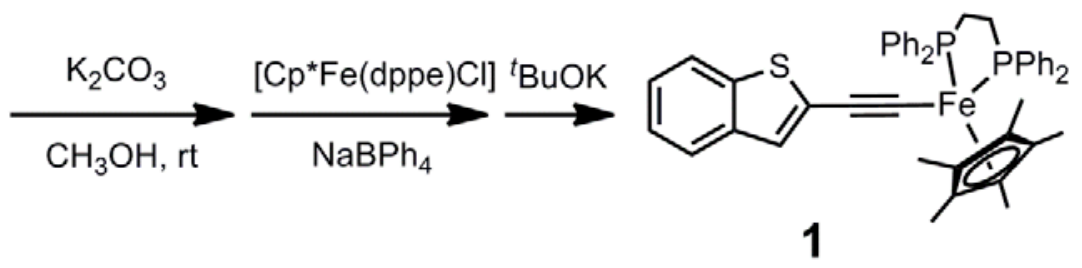




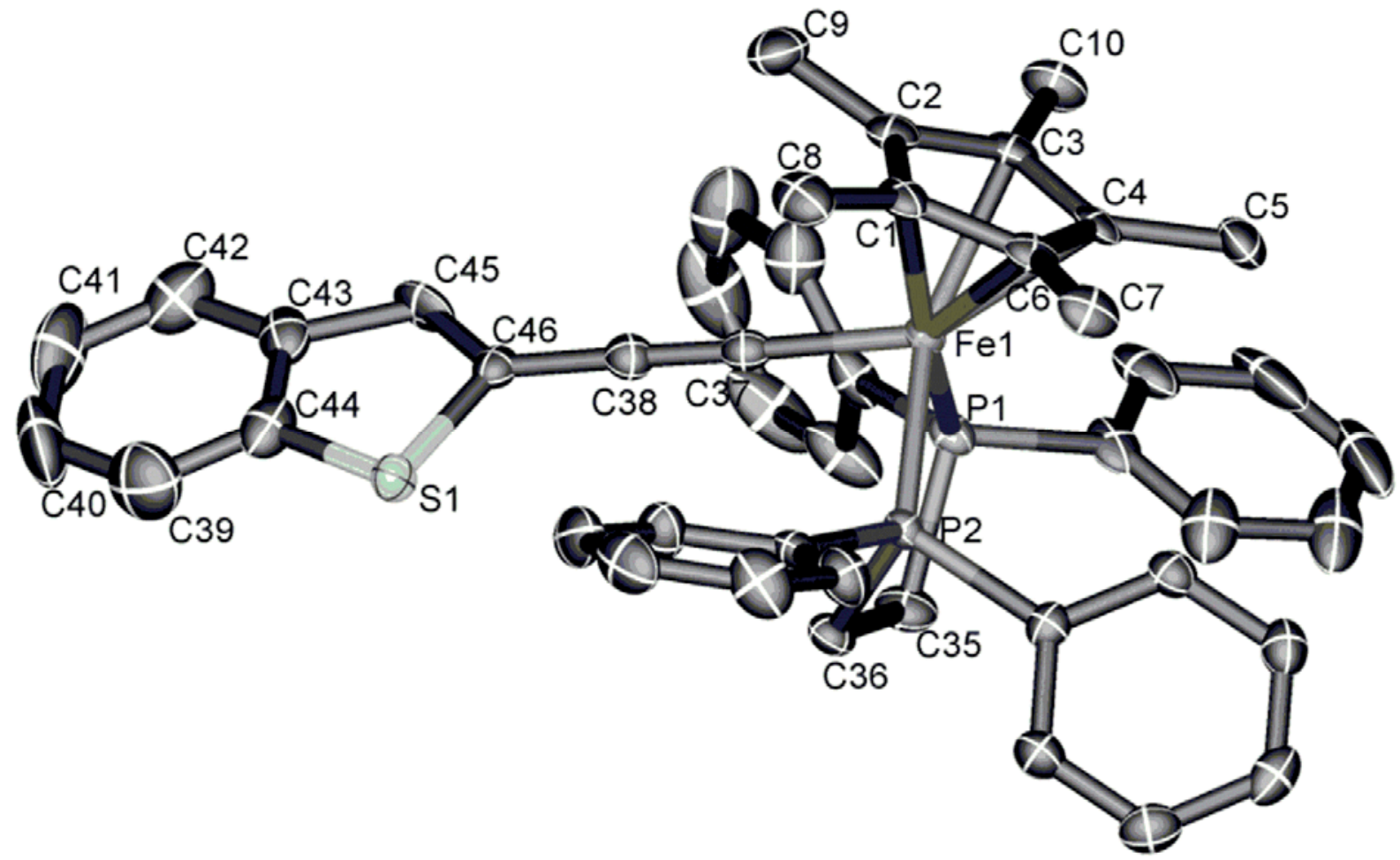



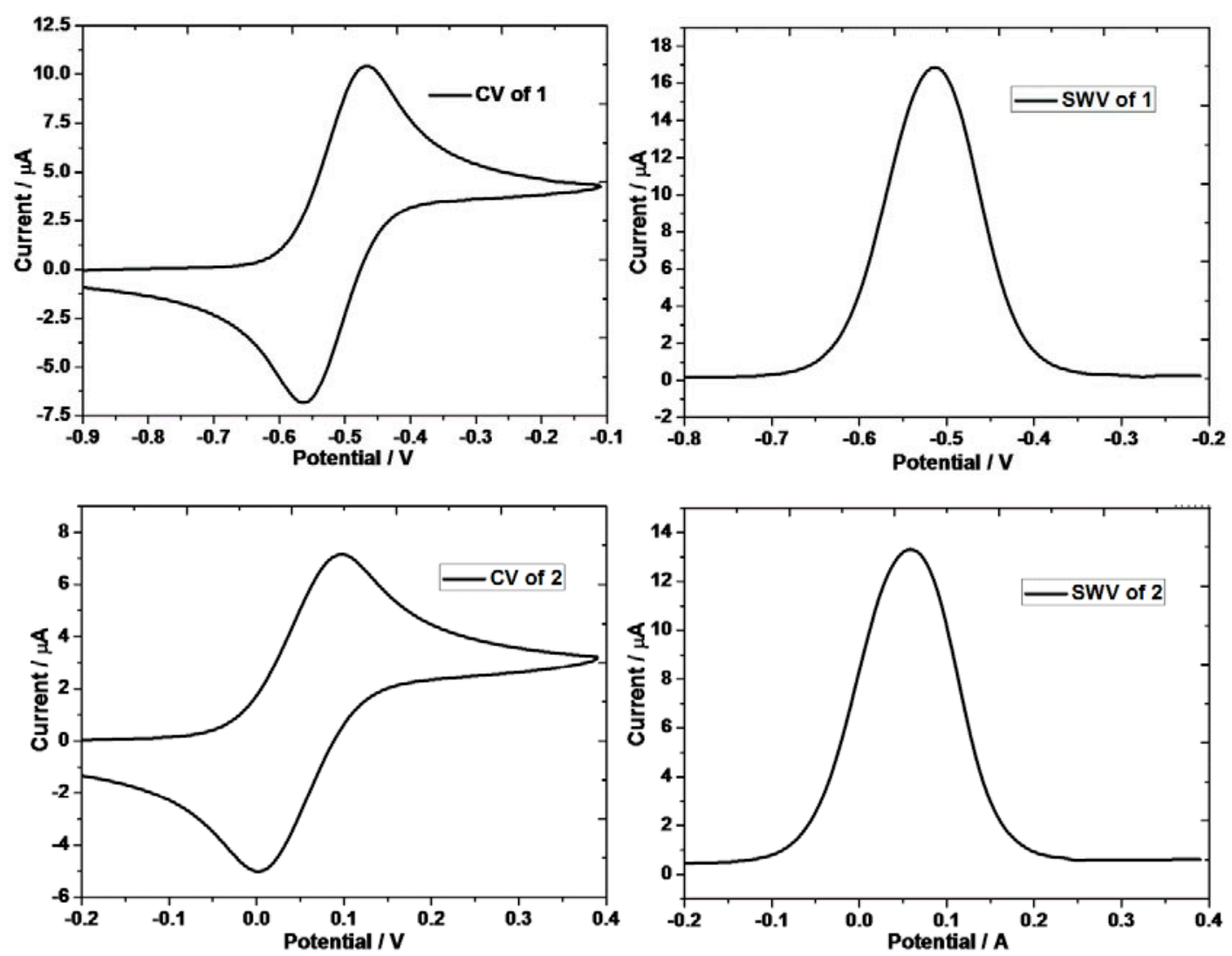

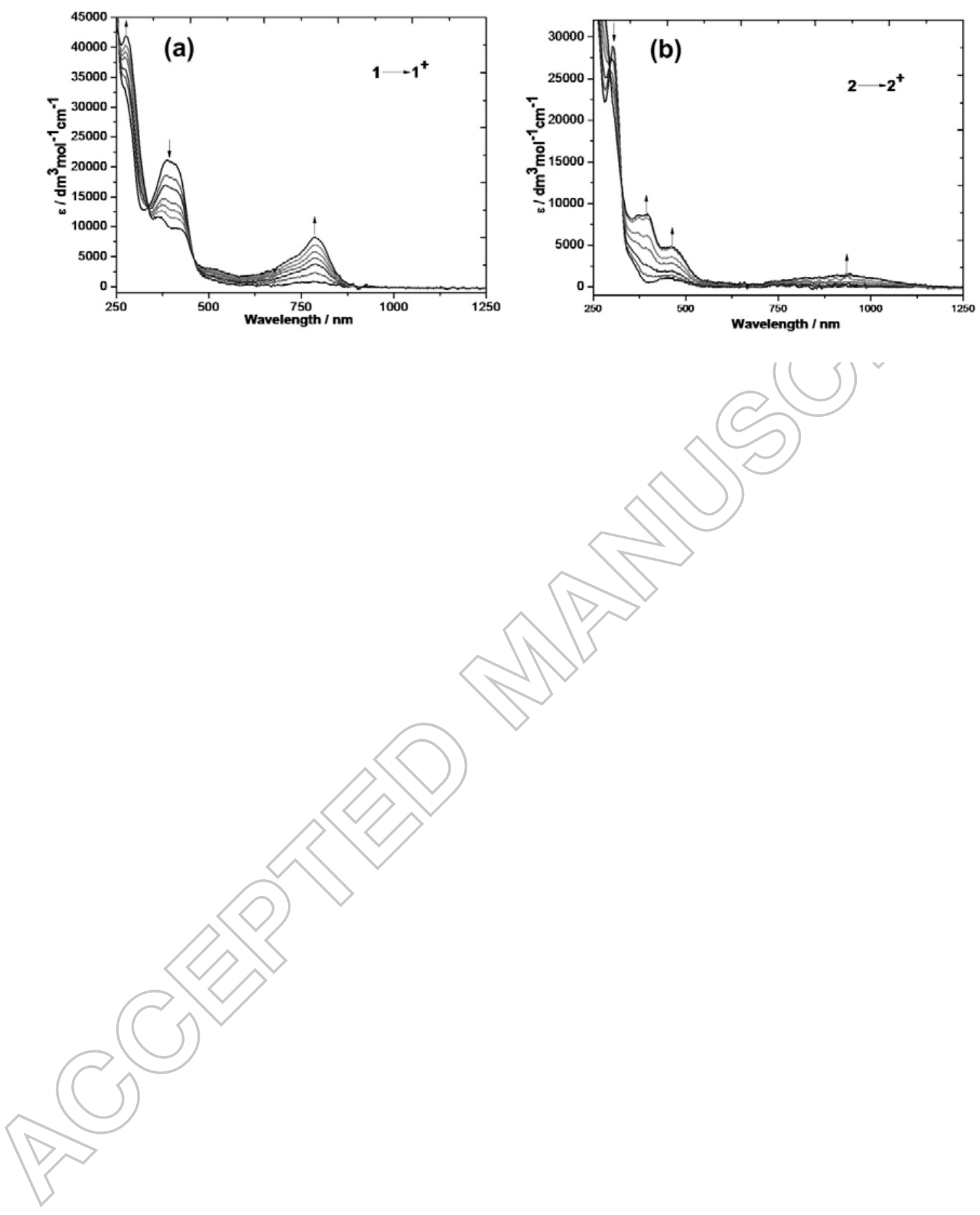

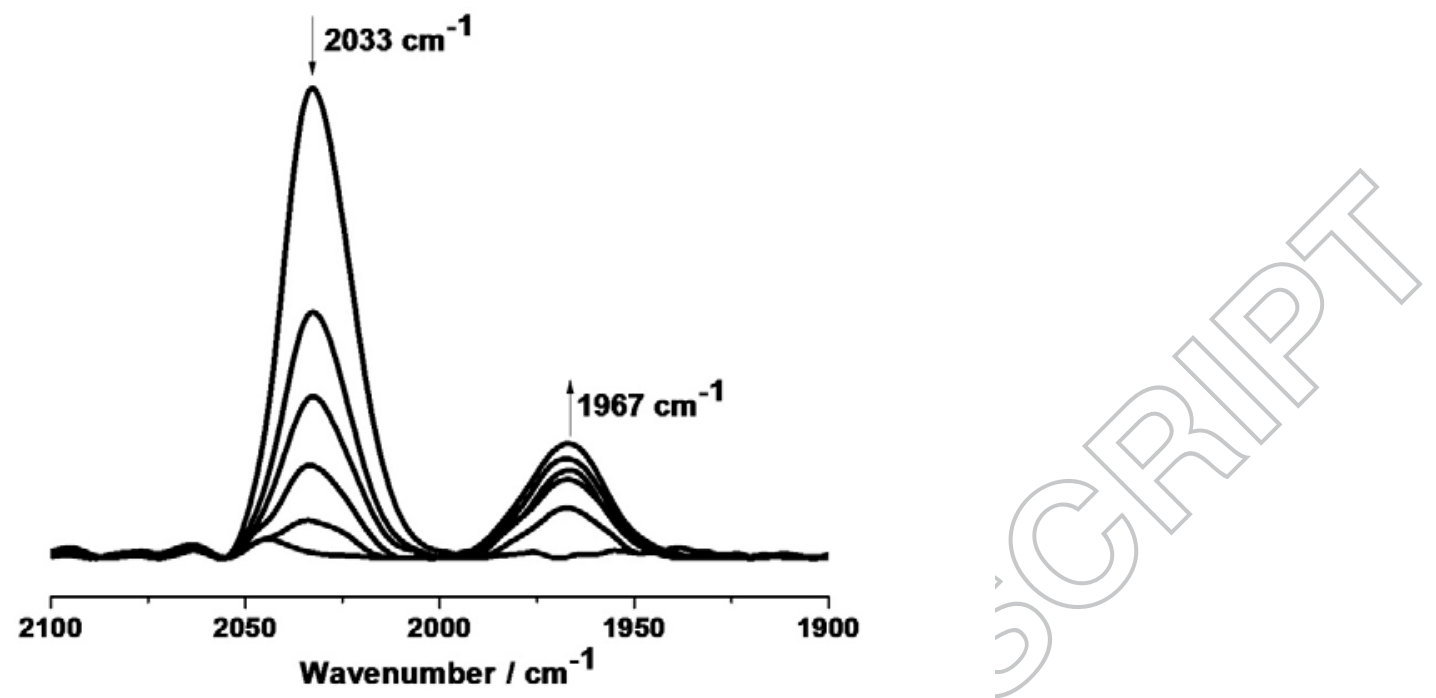


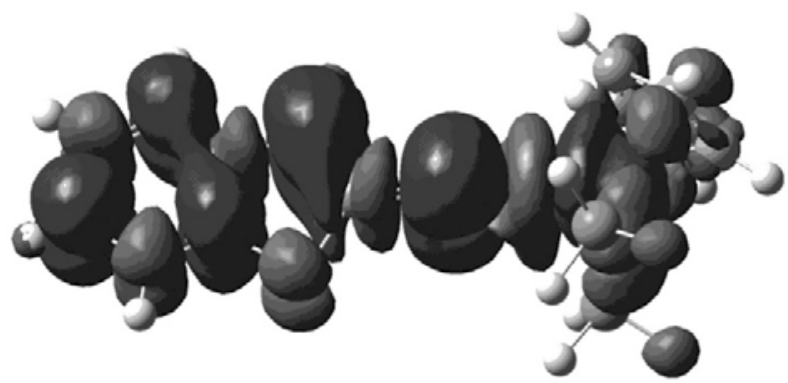

23 / 19 / 58

(a)

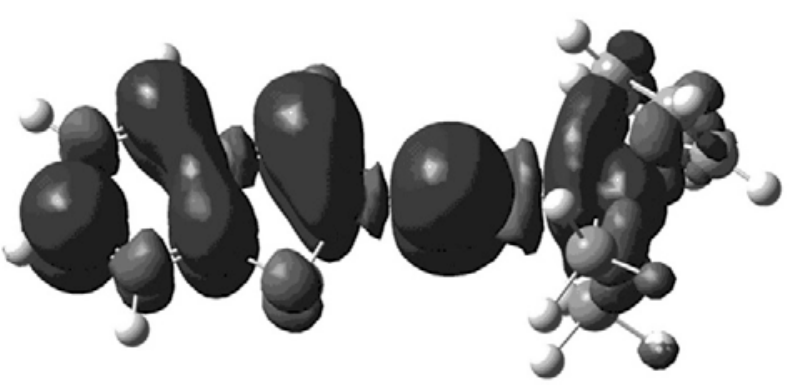

$15 / 8 / 77$

(b) 


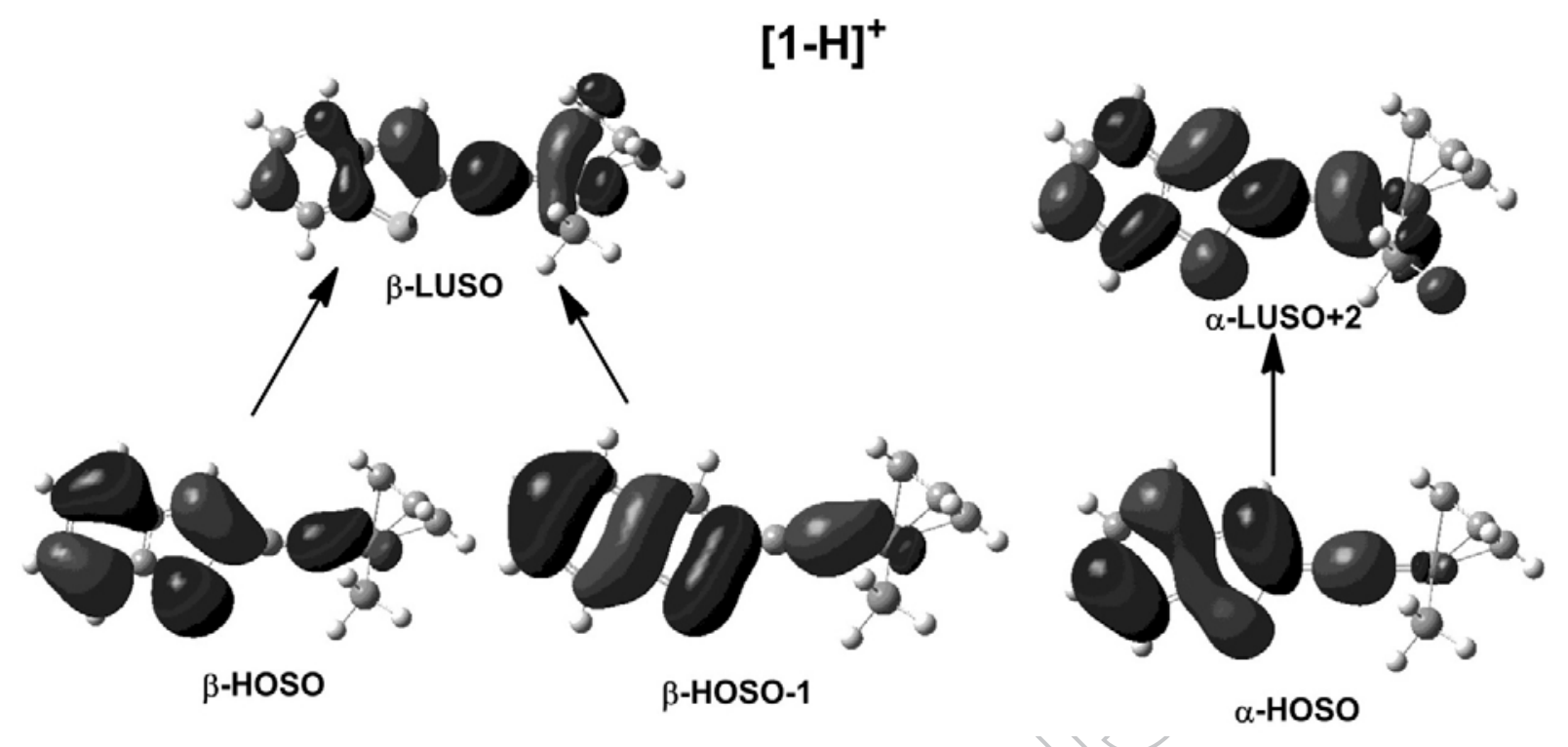




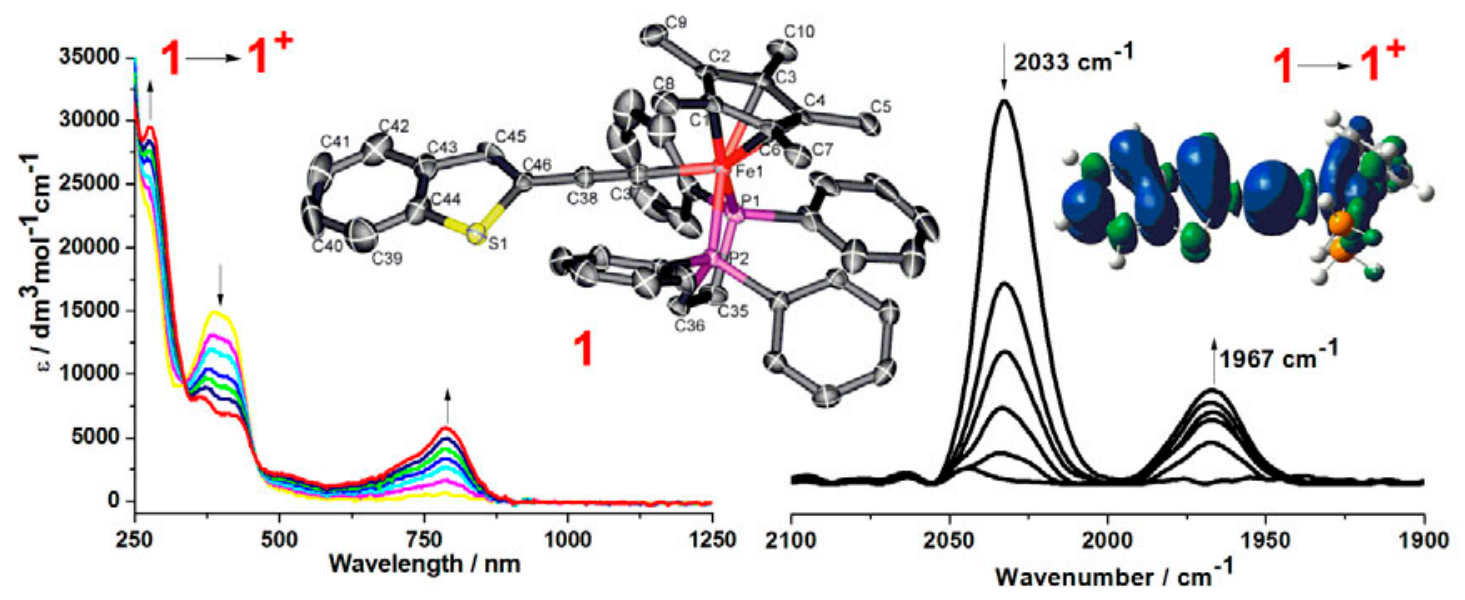

